\title{
A HELYI GAZDASÁGFEJLESZTÉS FOGALMI MEGHATÁROZÁSA
}

\author{
(Defining Local Economic Development)
}

\section{MEZEI CECÍLIA}

Kulcsszavak:

helyi gazdaságfejlesztés helyi gazdasági kezdeményezés helyi gazdaságfejlesztési eszközök lokális szint

Mivel nincs általánosan elfogadott helyi gazdaságfejlesztési definició, tanulmányunkban a kifejezés lehetséges értelmezéseinek szük körét mutatjuk be, mégpedig négy vizsgálati dimenzió (a fejlesztés mozgatói, a szuikséges eröforrások, a beavatkozás célja és terïleti hatóköre) mentén haladva, illetve meghatározva helyzetét más fejlesztési fogalmakhoz (helyi fejlesztés, közösségfejlesztés, vidékfejlesztés, területfejlesztés, településfejlesztés, regionális fejleszatés) képest.

\section{Bevezetés}

Az elmúlt évtizedekben a helyi gazdaságfejlesztés ismeretlen, rejtélyes fogalomból kơzhasználatú, a tudományos közeg mellett a politikai és a hétkơznapi életben is megjelenỏ kifejezéssé vált. Ugyanakkor nincs általánosan elfogadott helyi gazdaságfejlesztési definíció. A fogalmat sokan és sokféle értelemben használják, gyakran a pontos definíció rögzítése nélkül.

Tanulmányunkban ezért a helyi gazdaságfejlesztés értelmezéseit járjuk körbe, mégpedig a fejlesztés mozgatóira, a szukséges erőforrásokra, a beavatkozás céljaira és területi hatókörére fókuszálva. Elhelyezzük továbbá a helyi gazdaságfejlesztést a fejlesztési fogalmak rendszerében, benintatva a regionális fejlesztés, a területfejlesztés, a településfejlesztés, a helyi fejlesztés, a közösségfejlesztés és a vidékfejlesztés néhány definíciós változatát.

\section{A helyi gazdaságfejlesztés helye a fejlesztési fogalmak rendszerében}

Megpróbálva rendet tenni a különféle irányzatok és elméletek között, elsőként tisztázzuk, hogy a fejlesztés fogalma szigorú értelemben minőségi javulást eredményező beavatkozást jelent, melynek végsỏ célja a lakosság életszínvonalának növelése. Gazdaságfejlesztés alatt pedig olyan tudatos beavatkozásokat értünk, amelyek a gazdasági folyamatok irányát, a gazdasági változások mértékét hivatottak befolyásolni.

A helyi gazdaságfejlesztést el kell különítenünk olyan (szintén többféleképpen használt és értelmezett) fogalmaktól, mint a területfejlesztés, a telepủlésfejlesztés, a regionális fejlesztés, a helyi fejlesztés, a közösségfejlesztés vagy a vidékfejlesztés. 
Definiálva az egyes kifejezéseket láthatóvá válik, hogy a „fejlesztési” kulcsfogalmak esetében lehetnek átfedések területi vagy funkcionális szempontból.

A területfejlesztés Faragó László szerint olyan tudatos önkormányzati, kormányzati beavatkozást takar, mely során a közbelépők hatni próbálnak a különbözö tevékenységek térbeli megoszlására (EC 1997. idézi: Faragó 2001, 3) ${ }^{1}$, s amelynek köszönhetően bekövetkezhet az adott terület, térség fejlödése, ami a helyi társadalom szempontjából a lehetőségek bỏvüléseként jelentkezik (Faragó 1994). A területfejlesztés magában foglalja a területpolitikát ${ }^{2}$, a jogi szabályozást, az intézményrendszert, illetve a tervezést (Faragó 2001).

G. Fekete Éva (2001) szintén a területi folyamatokba való tudatos beavatkozásként definiálja a területfejlesztést.

A területfejlesztésrỏl és területrendezésrỏl szóló 1996. évi XXI. törvény a területfejlesztés fogalmán az ország egészét, valamint annak térségeit érintỏ területi folyamatok figyelését, értékelését; tervszerủ beavatkozási irányok meghatározását; valamint fejlesztési célok megfogalmazását és fejlesztési programok megvalósítását érti.

Regionális fejlesztés a régiók közötti egyenlőtlen fejlödés mérséklésére irányuló törekvések összessége, amely így a területpolitika egyetlen területi szintre vonatkozó részét, szegmensét képezi (Faragó 2001). Buday-Sántha Attila (2001, 20) szerint viszont a regionális fejlesztés a teruletfejlesztés szinonimája.

Általános nézet, hogy a telepuilésfejlesztés a területfejlesztés részét képezi (Faragó 1994; Péteri 2001; Finta 2004). A településfejlesztés ,szűkebb értelemben a lakosság élete szempontjából jelentősebb beruházások hatásainak számbavétele és megvalósítása" (Enyedi 2000 idézi: Farkas 2006, 71) ${ }^{3}$, tágabb értelemben pedig ,a települési folyamatok befolyásolására irányuló koncepcióalkotó, tervezési és végrehajtási tevékenységek összessége (Farkas 2006, 71). Faragó (1994) értelmezésében viszont a településfejlesztés a helyi fejlesztési politikát és a helyi kezdeményezésủ és finanszírozású tevékenységeket fogja át.

Buday-Sántha Attila szerint „a vidékfejlesztést a területfejlesztés sajátos területének, egyik, az agrártérségekre jellemző irányának tekinthetjük" (Buday-Sántha 2001, 20).

Részletezve, a vidékfejlesztés kiterjed mindazon tevékenységekre, ,amelyek a vidéki térségekben élö lakosság életminőségét, a környezeti és természeti táj, valamint a kultúrtáj megőrzését szolgálják, és megteremtik a vidéki térségek fenntartható fejlödését a vidék adottságainak, sajátosságainak megfelelỏen" (Kulcsár 1998 idézi: Farkas 2006, 88) ${ }^{4}$.

G. Feket Éva definíciójában „a vidékfejlesztés a vidéki térségben végbemenő változások alakulásába történő tudatos beavatkozásként értelmezhetö" (G. Fekete 2005, 14), az integrált vidékfejlesztés pedig a lokális, a regionális és a globális érdekek integrációját, illetve az egyoldalú agrárfejlesztés helyett egy komplex fejlesztési gyakorlatot (épített, társadalmi, gazdasági, természeti környezet) takar (G. Fekete 2005).

A helyi fejlesztés Puljiz (2004) értelmezésben a gazdaságin kívül felöleli a társadalmi, a demográfiai, a környezetvédelmi stb. dimenziókat is, tehát bỏvebb fogalom, mint a helyi gazdaságfejlesztés. 
G. Fekete Éva meghatározásában a helyi fejlesztés leglényegesebb vonása, megkülönböztető jele (más típusú fejlesztésekhez képest) annak bottom-up jellege. Fontos továbbá a helyi szint részvétele, mégpedig a folyamatok kezdeményezöjeként és ellenörzőjeként, illetve hangsúlyos a helyi társadalom önálló döntési kompetenciája, saját mozgástere (G. Fekete 2001).

A helyi fejlesztések kezdeményezöi, erőforrásai és szereplöi alapjăn azonban többféle helyi fejlesztési típust különböztethetünk meg (1. táblázat). Ezek közül külön figyelmet érdemel a közösségfejlesztés (community development), mivel azt sokan (Blakely-Bradshaw 2002) a helyi gazdaságfejlesztés részének tekintik; mások pedig attól bővebb fogalomként kezelik, amely a gazdasági kömyezeten túl felöleli olyan társadalmi kérdések rendezését is, mint az egészségügy, az oktatás, a lakáshelyzet vagy a környezet minösége (Čapková 2005).

\section{TÁBLÁZAT}

A helyi fejlesztések különbözö irányzatainak áttekintése (An Outline of Different Directions of Local Developments)

\begin{tabular}{|c|c|c|c|}
\hline \multirow[t]{2}{*}{ A fejlesztés kezdeményezői: } & Csak belsö & Belső és külső & $\begin{array}{c}\text { Nem } \\
\text { jellemzett }\end{array}$ \\
\hline & \multicolumn{3}{|c|}{ eröforrásokat von be } \\
\hline $\begin{array}{l}\text { Egyének, családok } \\
\text { Hátrányos kisközösségek }\end{array}$ & $\begin{array}{l}\text { grass roots } \\
\text { self-help }\end{array}$ & & \\
\hline $\begin{array}{l}\text { Kisközösségek (települési } \\
\text { vagy kistérségi) }\end{array}$ & & $\begin{array}{l}\text { (inter)community } \\
\text { economic } \\
\text { development }\end{array}$ & from below \\
\hline Helyi hatalom & & $\begin{array}{l}\text { local } \\
\text { development }\end{array}$ & \\
\hline Nem jellemzett & $\begin{array}{l}\text { self sufficient, } \\
\text { endogenous }\end{array}$ & bottom up & \\
\hline
\end{tabular}

Forrás: G. Fekete (2001, 17).

G. Fekete Éva (2000) a közösségfejlısztést azokra a beavatkozásokra szükíti le, amikor a globalizáció kihívásaira a piacgazdaság nem piaci szereplői adnak a helyi kỏzösség érdekeinek megfelelő választ.

Varga A. Tamás és Vercseg Ilona (1998) definíciója szerint a „közösségfejlesztés ... elsösorban települések, térségek, szomszédságok közösségi kezdeményezö- és cselekvöképességének fejlesztését jelenti, amelyben kulcsszerepuik van a polgároknak, közösségeiknek és azok hálózatainak, valamint a helyi szükségletek mértékében a közösségfejlesztóknek is, akiknek bátorító-ösztönzö, informáló, kapcsolatszervezö munkája életre segítheti, vagy kiegészítheti, megerösítheti a meglévő közösségi eröforrásokat" (idézi: Farkas 2006, 135) ${ }^{5}$.

A helyi gazdaságfejlesztés helye a fenti fogalomrendszerben - értelemszerüen más és más lehet. Puljiz (2004) például a tágabb helyi fejlesztés részének tekinti a helyi gazdaságfejlesztést. Mások szerint a gazdaságfejlesztés a területfejlesztés és lokális dimenzióban a településfejlesztés részét képezi (Péteri 2001; Finta 2004). 


\section{A helyi gazdaságfejlesztés értelmezése}

A helyi gazdaságfejlesztés fogalma kapcsán vita tárgyát képezi a helyi szint meghatározása, a lehetséges gazdaságfejlesztési beavatkozások típusai, kezdeményezöi, támogatói és a helyi fejlesztés erőforrásai. Ennek megfelelöen más-más fogalmi meghatározást találhatunk az egyes szerzöknél. A továbbiakban éppen ezért áttekintjük a szakirodalom meghatározó szerzőinek definícióit. A vizsgálatot a következő dimenziók mentén végezzük el (Wong 1996):

- ki a fejlesztés mozgatója, illetve milyen erőforrások szükségesek hozzá,

- milyen célok elérése érdekében folyik a beavatkozás,

- és a helyi gazdaságfejlesztés milyen területi dimenzióban történik?

\section{A fejlesztés mozgatói és a szuikséges eröforrások}

Syrett (1995) úgy definiálja a helyi gazdaságfejlesztését, hogy közben azt élesen elkülöníti a helyi kezdeményezések fogalmától. Míg az általános helyi szintủ fejlesztési folyamatra a helyi gazdaságfejlesztés kifejezést használja, a speciális tevékenységek végrehajtását és a vállalkozások létrehozását helyi gazdasági kezdeményezéseknek (local economic initiatives) tekinti. A felfogásból következik, hogy amíg a helyi gazdaságfejlesztést elindíthatja külső hatás is, például külső befektetések vagy központi kormányzati gazdaságpolitika, a helyi gazdasági kezdeményezések mindig a helyi szintről indulnak ki (2. táblázat).

\section{TÁBLÁZAT}

A helyi gazdaságfejlesztés és a helyi gazdasági kezdeményezés megkuilönböztetö jellemzöi

(Differential Characteristics of Local Economy Development and Local Economical Initiation)

\begin{tabular}{|c|c|c|}
\hline & Helyi gazdaságfejlesztés & $\begin{array}{c}\text { Helyi gazdasági kezde- } \\
\text { ményezés }\end{array}$ \\
\hline A fejlesztési folyamat & Általános folyamat & Konkrét tevékenység \\
\hline Kezdeményezö & Külsó és/vagy belső hatások & $\begin{array}{l}\text { Helyi kezdeményezés } \\
\text { és/vagy ellenórzés }\end{array}$ \\
\hline
\end{tabular}

Forrás: Saját szerkesztés.

A helyi gazdasági kezdeményezések alapvető jellemzője, hogy

- a lokális dimenzió, mint kulcsterület jelenik meg,

- akárcsak a munkahelyteremtés és a gazdasági megújulás,

- de a vállalkozó szellem és az innováció jelenléte is elengedhetetlen (Syrett 1995).

Stöhr (2001) szerint a helyi fejlesztés két formáját különbözethetjük meg, az egyik a központi hatáskörbe utalt fejlesztés (központi fejlesztési politika), a másik pedig a közösségi akcióknak vagy helyi kezdeményezéseknek hívott helyi fejlesztési 
tevékenységek. $A$ helyi kezdeményezés során elsősorban helyi erőforrásokat használnak, helyi ellenörzés mellett, fỏleg helyi haszon eléréséért. Ez utóbbi forma nem csupán a központi források hiánya miatt alakult ki, de azért is mivel a gyorsan változó környezetben kialakuló helyi problémákra a központi politika nem tudott megfelelỏ biztonsággal megoldást találni, hiszen ezen problémák alkalmazkodó és rugalmas akciókat igényelnek, melyek során a belső és a külső erőforrások felhasználását úgy kell optimalizálni, hogy a hely versenyképes maradjon a világpiacon. Mindez nagyobb mértékủ decentralizációt igényel a döntéshozatal, a helyi kezdeményezések és akciók tekintetében.

Blakely és Bradshaw (2002) szintén használja a helyi gazdasági kezdeményezés definícióját, amely olyan tervezett, tudatos tevékenységet takar, melynek végrehajtója lehet közösségi és magánszervezet is. A helyi gazdaságfejlesztés pedig olyan, a helyi önkormányzatok és a közösségi(irányítású) szervezetek által ösztönzött folyamat, amelynek célja az üzleti tevékenység és a munkahelyteremtés támogatása.

Bartik (1995) definíciójában a helyi gazdasági fejlödés nem más, mint olyan változások összessége, amelyek képessé teszik a helyi gazdaságot a jólét megteremtésére.

Ćapková (2005) átfogó stratégiaként azonosítja a helyi gazdaságfejlesztést, amelyben a helyi szereplök és intézmények a helyi eröforrások leghatékonyabb felhasználását tüzik ki célul.

Bennett értelmezése alapján a helyi gazdaságfejlesztés olyan szubnacionális (általában szubregionális) tevékenység, amely a helyi erőforrások és a jóléti, foglalkoztatási és társadalmi lehetôségek bővítését fogja át, és legtöbbször egy helyi önkormányzat területénél nagyobb térséget érint (Bennett 2000; Bennett-Krebs 1991).

Faragó saját elméleti fejtegetése során utal arra, hogy ,a helyi jelző sajátosan módosítja a gazdaságfejlesztés tartalmát. Olyan folyamatokra utal, amelyek egy régión belül hatnak, s valamilyen módon kötődnek az adott területhez" (Faragó 1990, 49). A helyi gazdaságfejlesztési folyamat olyan beavatkozás, amely a helyi érdekek elérése érdekében, helyi eröforrásokat felhasználva a helyi jólét növelése és a helyi gazdaság alkalmazkodóképességének javítása érdekében történik (Faragó 1990).

Wong (1996) úgy találta, hogy azon szerzők, akik megpróbálkoztak a helyi gazdaságfejlesztés definiálásával egy dologban egyetértettek, mégpedig abban, hogy a helyi gazdasági fejlödés nem más, mint változási és növekedési folyamat. Így a definíció körüli elméleti viták szerinte oda vezettek, hogy a helyi gazdasági fejlödés kifejezést a helyi fejlódési és változási folyamat leírására szokták használni, ahol a változások elindítója, ösztönzöje nem feltétlenül származik kizárólagosan a helyi szintröl (belülröl), és amely külső és belsö eröforrásokat egyaránt mozgósíthat.

\section{A helyi gazdaságfejlesztés célja}

A gazdaságfejlesztési folyamat alapvető célja sem teljesen egyértelmủ a szakirodalomban. Akadnak, akik kizárólag a termelékenység növekedését fogadják el eredményként (AEDC 1984 idézi: Wong 1996, 7)ㅇ․ A csak a szüken értelmezett gazdasági fejlödést elfogadó, és a GDP-t egyfajta „szuperindikátorként” kezelő közgaz- 
dászokon kívül találkozhatunk a természeti és a humán erőforrások szerepét is kihangsúlyozó és számba vevő kutatókkal (Anderson 1991; Ekins 1986; Miles 1985 idézi: Wong 1996, 7) ${ }^{7}$. A gazdasági dimenzió egyszerü elfogadását elvető szakemberek közé tartozik például Syrett (1995), aki a helyi kultúra vizsgálatának szükségszerüségét tartja a helyi gazdaságfejlesztési kutatások egyik sarokpontjának. Wilson (1995) szerint a helyi közösség társadalmi, kulturális és viselkedési jellemzöi éppoly meghatározóak, mint a gazdasági hatótényezők, vagyis a gazdasági és nem gazdasági faktorok együttes befolyásolását elfogadók népes táborát (Castells 1989; Cooke 1989; Esser-Hirsch 1989; Moulaert et al. 1993 idézi: Wilson 1995, 646) ${ }^{8}$ gazdagítja.

Bennett és Krebs (1991), valamint Bartik (1995) a munkahelyteremtést és a jólét növelését tekintették a helyi gazdaságfejlesztés alapfeladatának. Čapková (2005) saját definíciójában a munkahelyteremtés mellett a vállalkozásösztönzést emeli ki.

Faragó (1991) értelmezésében a helyi gazdaságfejlesztés általános célja a gazdaság fejlödése elött álló akadályok elhárítása, és a piaci tökéletlen múködés következményeinek kezelése. Elsödleges célja pedig a munkahelyteremtés.

Blakely és Bradshaw (2002) szintén a munkahelyteremtést tartja a helyi gazdaságfejlesztés alapcéljának, mégpedig azokban a szektorokban, amelyek hozzájárulnak a természeti erőforrások, illetve a humán és intézményi tőke hatékony felhasználásához.

Puljiz (2004) megfogalmazásában a vállalkozásfejlesztés a helyi gazdaságfejlesztés fö feladata, mivel a vállalkozások fokozott aktivitása automatikusan a helyi lakosság életminőségének javulását eredményezi, mégpedig a foglalkoztatás bővülése és az egyéni jövedelmek növekedése révén.

A helyi gazdaságfejlesztés célja tehát nem csupán a gazdasági növekedés elérése lehet, hanem olyan minóségi változások elérése is, mint a foglalkoztatás bővullése, a társadalmi problémák megoldása, a hozzáférés (lehetőségekhez, szolgáltatásokhoz) biztosítása vagy az életminőség javulása.

A helyi gazdaságfejlesztés célja idöben is változott (3. táblázat).

Tudjuk, hogy a helyi gazdaságfejlesztés elméletének kialakulásában fontos szerepe volt a világgazdaság 1970-es évekbeli változásának, mivel az olajválság elötti gazdaságpolitika sikertelennek bizonyult az új feltételek között. Az 1980-as évektöl az iparosítási politika is tarthatatlanná vált, a nemzetállamoknak új területpolitikai célokat kellett megfogalmazniuk, amelyekben már helyet kaptak a helyi kezdeményezések és az endogén erőforrások.

Az ekkor végbemenő változások hátterében a gazdasági globalizáció, az ún. információs társadalom, a fenntartható fejlődés szemlélete, az új típusú demokrácia és a területpolitikák paradigmaváltása együttesen álltak (G. Fekete 2001).

Ebben az új környezetben a helyi gazdaságfejlesztés célja kibővült, hiszen a helyi infrastruktúra biztosításán túl most már olyan egyedi támogatási csomagokat is ki kellett dolgozni, amelyek biztosították az adott település vagy térség növekvő versenyképességét a telephely-választási döntések befolyásolásában. 


\section{TÁBLÁZAT}

A helyi gazdaságfejlesztés idöbeli változása

(Change of Local Economy Development)

\begin{tabular}{|c|c|c|c|}
\hline $\begin{array}{l}\text { Idö- } \\
\text { tartam }\end{array}$ & $\begin{array}{c}\text { A helyi gazdaságfejlesztés } \\
\text { célja }\end{array}$ & $\begin{array}{c}\text { A helyi gazdaságfejlesztés } \\
\text { eszközrendszere }\end{array}$ & $\begin{array}{c}\text { A szerep- } \\
\text { lök }\end{array}$ \\
\hline $\begin{array}{c}1960- \\
1980 \text {-as } \\
\text { évek } \\
\text { eleje }\end{array}$ & $\begin{array}{l}\text { - Termelő beruházások támoga- } \\
\text { tása, külső befektetések (külö- } \\
\text { nösen a külföldi direkt befek- } \\
\text { tetések) vonzása. } \\
\text { - Infrastrukturális beruházások } \\
\text { (vonalas infrastruktúra). }\end{array}$ & $\begin{array}{l}\text { - Nagy összegü támogatások } \\
\text { nyưjtása. } \\
\text { - Kedvezményes kölcsönök biz- } \\
\text { tosítása a helyi beruházásokat } \\
\text { végző termelő vállalatoknak. } \\
\text { - Adókedvezmények nyújtása. } \\
\text { - Az infrastrukturális beruházá- } \\
\text { sok támogatása. }\end{array}$ & $\begin{array}{l}\text { Csak } \\
\text { közösségi } \\
\text { részvétel. }\end{array}$ \\
\hline
\end{tabular}

1980 - A helyi vállalkozások megtar- - Egyedi vállalkozások közvet1990-es tása és támogatása. len pénzügyi támogatása.

évek - A beruházások kiemelt szere- - Inkubátorházak, munkahelyteközepe pe, de már jóval célzottabban remtỏ támogatások.

Az együttmüködések közösségi irávagy a támogatott szektorok, - A kis- és középvállalkozások nyítása. vagy a támogatott területi egységek tekintetében. támogatása (tanácsadás, képzés).

- Technikai segítségnyújtás.

- $\mathrm{Az}$ induló vállalkozások támogatása.

- Néhány humán és fizikai infrastrukturális beruházás támogatása.

1990- - A közvetlen vállalati támogatások helyett a teljes (versenyképes) üzleti környezet alakítása a cél.

- A humán infrastrukturális beruházások támogatása.

- A hálózatosodás elősegítése, és a magánszektor beruházásainak befolyásolása.

- A hely versenyképességének fokozása érdekében a beruházások fokozott ösztönzése.
- Megfelelö környezet kialakí- A közöstása a helyi vállalkozások fej- ségilödésének elösegítéséhez. magán

- Versenyképes helyi telepítési együttmütényezők biztosítása.

- Az együttmúködések és a hálózatok ösztơnzése. ködések preferálása, az együttmüködések közösségi vezetése.

Forrás: The World Bank (2005) alapján saját szerkesztés. 
Majd a közvetlen vállalkozói támogatásokat és a külső befektetök vonzását felváltotta a vállalkozások megtartásának igénye, illetve a támogatások területi és ágazati koncentrációja. A folyamat végén a hálózatosodás ösztönzése és a vállalkozóbarát környezet kialakításának igénye fogalmazódott meg célként a helyi gazdaság fejlesztői elött.

A helyi gazdaságfejlesztési célkitüzések módosulása egyúttal a gazdaságfejlesztési eszközrendszer változását is eredményezte: a közvetlen vállalati támogatások helyét egyre inkább átvette a versenyképesség növelését szolgáló közvetett gazdaságfejlesztési eszközök alkalmazása.

E módosuló célrendszerben jelenik meg a külső gazdaságosság biztosításának követelménye, amely egyre inkább elvárásként fogalmazódik meg a vállalkozások részéröl egy-egy telephellyel, településsel szemben. A helyi gazdaságfejlesztés során most már a település egészét kell vonzóvá tenni - meg kell teremteni azt a miliöt, amely a vállalkozások müködését "támogatja". Fontos tényezö lehet pl. a lakókörnyezet minősége, a környezet állapota, a munkaerő képzettsége, rugalmassága, a munkakultúra, az iparág illetve a munkaerőpiacok specializációja stb. (Faragó 1990; Wilson 1995; Stöhr 2001; Hrubi 2004).

\section{A helyi gazdaságfejlesztés területi dimenziója}

További vizsgálódást igényel, hogy vajon a helyi gazdaságfejlesztés kifejezés „local” azaz „helyi” része milyen területi kategóriára utal. Egyetértve Lengyel Imre azon megállapításával, mely szerint a lokális szint konkrét meghatározása földrajzi, közigazgatási, történelmi stb. tényezőktöl függ (Lengyel 2003), el kell fogadnunk, hogy gyakran szerzőnként, esetenként a vizsgált kutatási terület kívánalmainak megfelelően változik a lokális szint lehatárolása.

Az általunk áttanulmán yozott helyi gazdaságfejlesztési szakirodalomban „lokális” alatt legtöbbször a regionális szintet értik, söt gyakran szinonimaként használják a két jelzöt. A helyi gazdaságfejlesztési szakirodalom egyik fö irányzata (Pálné Kovács 2003; Horváth 1998) szerint a hatékonyság, a versenyképesség és a siker elvárása megköveteli a helyi szereplök térségi együttmüködését, a regionális koordinációt és az erőforrás-koncentrációt.

Lengyel Imre (2003) viszont a versenyképességi vizsgálatok legkisebb mérhetó egységével, azaz a munkaerö-vonzáskörzettel azonosítja a (gazdasági) térséget, teszi ezt annak tudatában, hogy több korábbi kutatás (de Vet 1993; OECD 2001; Rechnitzer 1998) ${ }^{9}$ során használták már ezt a fogalmi meghatározást. Bennett és Krebs (1991) szintén a helyi munkaerö-piaci térséget érti lokális szint alatt, pontosabban a helyi gazdaságfejlesztésben érintett területi egységként. Cooke $(1986)^{10}$ vizsgálatai pedig kimutatták, hogy 31, a témához kapcsolódó kutatásnak több mint a fele munkaerö-piaci egységgel foglalkozik (idézi: Wong 1996, 9).

G. Fekete Éva a helyi fejlesztések kérdéskörén belül a kistérségek (NUTS 4) fejlesztési lehetőségeit vizsgálta behatóan ( $G$. Fekete 2001). Bennett és Krebs (1994) az EU LEDA programjának akcióterületeit, azaz szubregionális térségeket és városokat hasonlított össze a helyi munkahelyteremtést támogató együttmúködések szempontjából. 
A Világbank fóként a városok fejlesztéséhez kapcsolódóan foglalkozik a helyi gazdaságfejlesztéssel (The World Bank 2005). Reese (1997) kanadai és amerikai városok helyi gazdaságfejlesztési gyakorlatát kutatta. McGuire (2000) és a Basolo-Huang (2001) páros amerikai városok körében végzett empirikus kutatást, és Bartik (1995) is amerikai városkutatások eredményeit mutatja be.

Természetesen találhatunk példát a lokalitás helyi önkormányzati egységként (nem feltétlenül esik egybe a településsel) való értelmezésére is. Bennett (1998) például 1998-ban angol és walesi helyi önkormányzatok körében végzett helyi gazdaságfejlesztéssel foglalkozó kutatást. A Local Futures Group 2004-es vizsgálata NagyBritannia helyi önkormányzati kerületeivel (district) foglalkozik, kategorizálva mind a 408 kerületet azok gazdasági fejlődése szempontjából (Hepworth 2004). Ide sorolhatjuk továbbá Syrett-nek (1995) a portugál Központi Régió helyi önkormányzataihoz kiküldött kérdőíves felmérését, ahogyan Wong (1998) angliai kutatását, valamint Young és Kaczmarek (2000) lengyel helyi önkormányzatokra kiterjedö vizsgálatát is. Puljiz (2004) és Čapková (2005) szintén ezt a nézópontot választották délkelet-, illetve közép-kelet-európai vizsgálataikhoz.

Hozzátesszük, hogy a helyi gazdaságfejlesztési kutatások során a lokális szint értelmezését nagymértékben meghatározza a gazdaságfejlesztési feladatok telepítésének és szabályozásának gyakorlata az adott országon belüi.

Összegezve, a „helyi” szint mindig is relatív és csak összefüggéseiben vizsgálható, meghatározó része lesz a helyi gazdaságfejlesztési kutatásoknak, vagyis a kutatás első lépéseként azt kell definiálnunk, hogy mit értünk helyi szint alatt. Csak a helyi szint lehatárolása után dölhet el, hogy mely szereplökre és milyen eröforrásokra kiterjedően értelmezzük a gazdaságfejlesztési tevékenységet.

\section{Összegzés}

A fent bemutatott definíciós kavalkád arra készteti a helyi gazdaságfejlesztés területén vizsgálódó kutatót, hogy állást foglaljon az egymás mellett élő, vagy éppen egymásnak ellentmondó értelmezési lehetőségeket illetỏen, azaz megalkossa a saját definícióját (Mezei 2006).

Saját értelmezésünk szerint a helyi gazdaságfejlesztés olyan, a helyi gazdaság életébe történó, külsö és/vagy belsö eröforrásokat hasznositó, tudatos beavatkozás, melynek kezdeményezöje lehet külső szereplö is (pl. kormányzat, EU, külföldi tőke), de a folyamat kulcsa mégis a helyi szereplök részvétele, akik vagy kezdeményezöként, vagy a kiulsö fejlesztési elképzelés elfogadóiként, támogatóiként és alakítóiként lépnek fel.

Nézetünk szerint a piaci folyamatokba csak közösségi felhatalmazás alapján lehet beavatkozni (Faragó 1990; Bennett-Krebs 1991; Blakely-Bradshaw 2002), így a helyi önkormányzatokat gyakorlatilag kihagyhatatlannak tartjuk a helyi gazdaságfejlesztésből, de más közremúködök részvétele is sikerfeltétel.

A helyi gazdaságot érintỏ beavatkozásokat tágan értelmezzük, bele tartozik az infrastruktúrafejlesztés, a szolgáltatásfejlesztés, a humánerőforrás-fejlesztés, a vállalkozásfejlesztés, az ún. külső gazdaságosság biztosítása és a közösségfejlesztés is. 
Čapková (2005) szerint Közép-Kelet-Európában ez a tágabb értelmezésủ, társadalmi-gazdasági fejlesztési gyakorlat honosodott meg, így a vizsgálatokat is erre kell összpontosítani.

A hazai helyi gazdaságfejlesztési kutatások változatos területi hatókörrel rendelkeznek, hiszen azok kiterjednek a régiók (Pálné Kovács 2004), a megyék (Hrubi 2004), a kistérségek (G. Fekete 2001) és a települések (Horváth-Péteri 1993; Horváth-Kiss 1996; Mezei 2004) vizsgálatára is.

\section{Jegyzetek}

${ }^{1}$ EC (1997) The EU compendium of spatial planning systems and policies. Office for Official Publications of the European Communities, Luxemburg.

${ }^{2}$ A terïletpolitika ,a területi struktúrák tudatos alakítása során követett prioritások, és az ezek eléréséhez használt eszközök és intézmények meghatározását és egyeztetését" jelenti (Faragó 1994, 25).

${ }^{3}$ Enyedi Gy. (szerk.) (2000) Magyarország telepiiléskïrnyezete. MTA, Budapest.

${ }^{4}$ Kulcsár L. (1998) Vidékfejlesztés és vidékpolitika Magyarországon. - A Falu. 4.

${ }^{5}$ Varga A.T.-Vercseg I. (1998) Közösségfejlesztés. Magyar Müvelödési Intézet, Budapest.

${ }^{6}$ AEDC (1984) Economic Development Today. AEDC, Chicago.

${ }^{7}$ Anderson, V. (1991) Alternative Economic Indicators. Routledge, London. Ekins, P. (1986) The Living Economy. Routledge and Kegan Paul, London. Miles, I. (1985) Social Indicators for Human Development. Frances Pinter, London.

${ }^{8}$ Castells, M. (1989) The Informational City. Blackwell, Oxford. Cooke, P. (ed.) (1989) Localities: The Changing Face of Urban Britain. Unwin Hyman, London. Esser, J.-Hirsch, J. (1989) The crisis of fordism and the dimension of 'postfordist' regional and urban structure. - Journal of Urban and Regional Research. 13, 417-437. o.

Moulaert, F, et al. (1993) Integrated Area Development and Efficacy of Local Actions. IFRESI, Lille.

${ }^{9}$ de Vet, J.M. (1993) Globalization and local and regional competitiveness. - OECD ST/ Review. 13. 89-112. o. OECD (2001) OECD területi vizsgálatok: Magyarország. MTA RKK, Pécs. Rechnitzer J. (1998) Területi stratégiák. Dialóg Campus Kiadó, Budapest-Pécs.

${ }^{10}$ Cooke, P.N. (ed.) (1986) Global Restructuring, Local Response. Economic and Social Research Council, London.

\section{Irodalom}

Bartik, T.J. (1995) Economic development strategies. - Upjohn Institute Staff Working Papper. 33. Klamazoo, Michigan, W.E. Upjohn Institute for Employment Research. - http://www.upjohninst.org/ publications/wp/95-33.pdf - 2006.03.25.

Basolo, V.-Huang, C. (2001) Cities and economic development: Does the city limits story still apply? Economic Development Quarterly. 4. 327-339. o.

Bennett, R.J. (1998) Survey of Local Economic Development (LED) Activity in Local Government. http://www.lga.gov.uk/lga/economicregeneration/survey.pdf - 2003.02.06.

Bennett, R.J. (2000) Regional and local economic development policy: The role of administration and political entrepreneurs. - Horváth, Gy. (ed.) Regions and Cities in the Global World. Centre of Regional Studies, HAS, Pécs, 58-81. o.

Bennett, R.J.-Krebs, G. (1991) Local Economic Development. Public-Private Partnership Initiation in Britain and Germany. Belhaven Press, London-New York.

Bennett, R.J.-Krebs, G. (1994) Local Economic Development Partnerships: An Analysis of Policy Networks in EC-LEDA Local Employment Development Strategies. - Regional Studies. 2. 119-140. o.

Blakely, E.J.-Bradshaw, T.K. (2002) Planning Local Economic Development. Theory and Practice. Sage Publications Ltd., London. 
Buday-Săntha A. (2001) Agrárpolitika - Vidékpolitika. A magyar agrárgazdaság és az Európai Unio. Dialóg Campus Kiadó, Budapest-Pées.

Ćapková, S. (2005) Local Government and Economic Development, - Čapková, S. (ed.) Local Government and Economic Development. Open Society Institute, Budapest. 1-19. o.

Faragó L. (1990) A helyi gazdaságfejlesztés elmélete. - Gazdasági Fórum. 2. 44-55. o.

Faragó, L. (1991) Local Economic Development. - Horváth, Gy. (ed.) Regional Policy and Local Governments. Centre of Regional Studies, HAS. Pécs. 71-81. 0.

Faragó L. (1994) Adalékok a területfejlesztéssel kapcsolatos fogalmak vitájâhoz. - Tér és Társadalom. 3-4. 23-38. o.

Faragó L. (2001) A területfejlesztéssel és területi tervezéssel kapcsolatos uniós fogalmak tartalma és használata. - Falu, Város, Régió. 3. 3-5. o.

Farkas P. (2006) Egymásba Kapaszkodva. Település- és kỏzösségfejlesztés a globalizáció korában. L'Harmattan Kiadó, Budapest.

Finta I. (2004) A helyi-területi szintű kỏzigazgatási szervezetek gazdaságirányítási, támogatásifejlesztési funkcióinak jogszabályi háttere. - Pálné Kovács I. (szerk.) Versenyképesség és igazgatás. MTA RKK, Pécs. 35-56. o.

G. Fekete É. (2000) A siker titkai a kistérségi fejlesztésekben. - Kovács T. (szerk.) Integrált vidékfejlesztés. V. Falukonferencia. MTA RKK, Pécs. 54-62. o.

G. Fekete É. (2001) Együtt - de hogyan? Innovációk a kistérségi fejlesztésekben. MTA RKK. MiskolcPécs.

G. Fekete É. (2005) Vidékpolitika (1.). Oktatási segédanyag a vidék-és helyi fejlesztés tárgyhoz Miskolci Egyetem Világ- és Regionális Gazdaságtan Intézet, Miskolc.

Hepworth, M. (2004) State of the Nation 2005. The geography of opportunity in 21st century Britain. The Local Futures Group, London.

Horváth Gy. (1998) Európai regionális politika. Dialóg Campus Kiadó, Budapest-Pécs.

Horváth M.T.-Kiss J. (szerk.) (1996) Aréna és otthon. Politikai Tanulmányok Intézete Alapítvány, Budapest.

Horváth M.T.-Péteri G. (1993) Új változatosság. Politikai keretek és gazdalkodási stratégiák az önkormányzatokban. „Helyi demokrácia és újítások” Alapítvány, Budapest.

Hrubi L. (2004) A megyék gazdaságfejlesztési szerepe. - Pálné Kovács I. (szerk.) Versenyképesség és igazgatís. MTA RKK, Pécs. 161-177. o.

Lengyel I. (2003) Verseny és területi fejlődés: Térségek versenyképessége Magyarországon. JATE Press, Szeged.

McGuire, M. (2000) Collaborative policy making and administration: The operational demands of local economic development. - Economic Development Quarterly. 3. 278-291. o.

Mezei C. (2004) Önkormányzati gazdaságfejlesztési gyakorlat a hazai településeken. - Pálné Kovács I. (szerk.) Versenyképesség és igazgatás. MTA RKK, Pécs. 181-265. o.

Mezei C. (2006) Helyi gazdaságfejlesztés Közép-Kelet-Európában. - Tér és Társadalom. 3.

Pálné Kovács I. (2003) A teriiletfejlesztés irányítása. PTE KTK Regionális Politika és Gazdaságtan Doktori Iskola Habilitációs Elöadások sorozata. PTE KTK, Pécs.

Pálné Kovács I. (2004) A regionális gazdaságfejlesztés irányítási összefuiggései. - Pálné Kovács I. (szerk.) Versenyképesség és igazgatás. MTA RKK, Pécs. 11-31. o.

Pêteri G. (2001) A teriilet-és telepúlésfejlesztés vállalkozási formái. - Beluszky P. (szerk.) A terület-és településfejlesztés kézikönyve. CEBA Kiado. Budapest. 139-143. o.

Puljiz, J. (2004) Economic Development. - How to Improve Development on Local Level? Handbook with Best Practice Examples from South-East Europe. Friedrich Ebert Stiftung, Zagreb. 9-24, o.

Reese, L.A. (1997) The use of planning methodologies in local economic development decision-making. - Environment and Planning. C: Government and Policy, 3. 285-303, o.

Stöhr, W.B. (2001) Subsidiarity: A Key Concept for Regional Development Policy. - Stöhr, W.B. et al. (eds.) New Regional Development Paradigms. Volume 3: Decentralization, Governance, and the New Planning for Local-Level Development. Greenwood Press, London. 35-51. o.

Syrett, S. (1995) Local Development: Restructuring, Locality and Economic Initiative in Portugal. Ashgate Publishing Company, Avebury.

A terilletfejlesztésröl és a terilletrendezésröl szól6 1996. évi XXI. törvény.

Wilson, P.A. (1995) Embracing Locality in Local Economic Development. - Urban Studies. 4-5. 645-658. o.

Wong, C. (1996) What is local economic development? A conceptual overview. - Occasional Paper. No. 49. Department of Planning and Landscape, University of Manchester.

Wong, C. (1998) Determining factors for local economic development: The perception of practitioners in the North West and Eastern Regions of the UK. - Regional Studies. 8. 707-720. o. 
The World Bank (2005) Local Economic Development. - http://web.worldbank.org/wbsite/external/ topics/exturbandevelopment/extled/0, menuPK:341145 pagePK:149018 piPK:149093 theSitePK:34 1139,00.html-2005.05.30.

Young, C.-Kaczmarek, S. (2000) Local government, local economic development and quality of life in Poland. - GeoJournal. 2-3. 225-234. o.

\section{DEFINING LOCAL ECONOMIC DEVELOPMENT}

\section{CECÍLIA MEZEI}

The study deals with the definition of local economic development (LED). Local economic development is a fashionable term, but the meaning of LED depends on who uses it and where it is used. The purpose of this article is to present some LED definition from the international academic literature. This research pays specific attention to the four dimensions of LED definition (Wong 1996):

- Who are the driving forces of LED?

- What are the required resources?

- What are the objectives aimed for?

- What is the spatial dimension of LED activities?

The article concludes with our LED definition. In our interpretation local economic development means conscious intervention into the local economy. In the course of that process the actors may use internal and external resources too. The initiator of intervention may be external actors (e.g. government, European Union, foreign investment), but the key element of process is the involvement of local actors, who are the initiators of LED activities, or acceptors, or supporters, or manipulators of external development conception.

We use the local economic development term in a wider sense, so the intervention into the local economy includes infrastructure development, development of public utilities, human resources development, business development, creation of internal economies, and community development too. 